\title{
Conservative management of Thrombosed external hemorrhoid
}

\author{
Muslim Kandel Kadem
}

Thi Qar University - Medicine College

\section{Abstract}

A prospective study of 20 patients (12 males ,8 female) with main age about 47 years in both sexes all were complained from thrombosed external hemorrhoid (TEH) was conducted, most of them complained from at least one symptom discharge , pain , lump....

As we know the surgical management is the gold standard management of such conditions , but in this study .( because some patients refuse operation either afraid from operation or shying specially women in our society ) so try conservative management No surgery, no baths, but treated with gentle dry cleaning with smooth toilet paper after defecation, with intravenous antibiotics (cefetriaxazon, metronidazol) for 2 weeks then Follow-up information was collected six months after admission the results are :- $6 \mathrm{Pt}(30 \%)$ (described as "healed" without need operation), $10 \mathrm{Pt}(50) \%$ (described as unchanged with minimal symptom no need another operation), 4pt (20\%) become sever pain or abscess formation need urgent operation.

Only 2 pt out of $16(12.5 \%)$ have recurrence. In spit of the surgery is the gold standard therapy for TEH butwe can use conservative management especially for patients who were unfit for surgery or who refused with minimal risks.

\section{العلاج التحفضي للبواسير الخارجية المتخثرة \\ مسلم قنديل كاظم$$
\text { كليه الطب - جامعه ذي قار }
$$

الخلاصة

دراسة مستقبليه أجريت على 20 مريضا (12 رجلا و8 ونساء معدل أعمارهم 47 سنه لكلا الجنسين) جميعهم مصابون بالبواسير

الخارجية المتخثرة اللذين يرفضون إجراء العمليه الجراحيه اما بسبب الخوف من العمليه او بسبب الخجل وخصوصا النساء في مجتمعنا المحافظ حيث اجريت علاجا تحفضيا بدون إجراء عمليه جراحيه (مع العلم ان العمليه الجراحيه هي العلاج الامنل لمثل هذه الحالات) كان العلاج عباره استخدام ورق التواليت الجاف الرقيق المعقم للمسح بعد التغوط دون استخدام الماء مع استخدام المضادات الحيويه

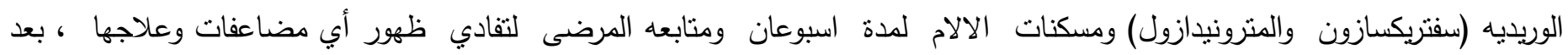
وبعد ذللك متابعه المرضى لمده 6 اثهر لاحتماليه رجوع المرض فوجدت مايلي :-

6مرضى (30\%) قد شفوا تماما ولم ييقى لها اثر الا قليل و 10مرضى (50\%) لـ تتغير الباسوره لم تشفى ولكن باعراض اقل ، اما المرضى الاربعه المنتقين (20\%) لم يفلح العلاج معهم فعانوا من الم شديد او تحول الى خراج مما اضطرنا الى اجراء عليه طارئه . 


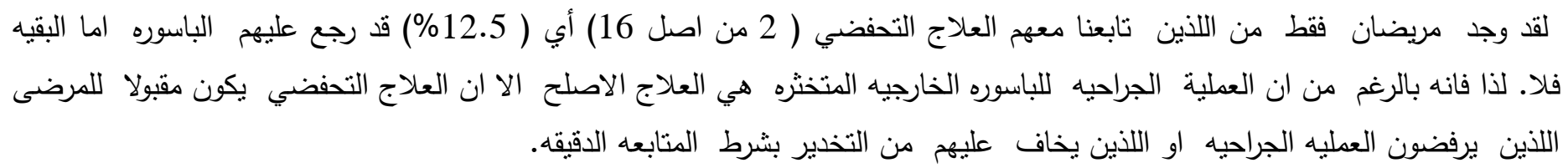

\section{Introduction}

External hemorrhoids (piles) occur distal to the dentate line and develop as a result of distention and swelling of the external hemorrhoidal venous system (see the first image below) (1)Engorgement of a hemorrhoidal vessel with acute swelling may allow blood to pool and, subsequently, clot; this leads to the acutely thrombosed external hemorrhoid, a bluish-purplish discoloration often accompanied by severe incapacitating pain $(2,3)$

Symptoms of benign anal diseases like internal hemorrhoids rank among the most common complaints of patients seen in primary care practices (4567). Etiology of thrombosed external hemorrhoid (TEH) is unknown (8)Synonyms for thrombosed external hemorrhoid are acute thrombosed external hemorrhoid, $(9,10)$ acute hemorrhoidal disease, ( 11) anal hematoma, perianal hematoma, $(12,13,14,15)$ thrombosed haemorrhoid, hemorrhoidal thrombosis $(16,13,17$ ) or perianal thrombosis. It was suggested to rename the disease "perianal thrombosis" to make it distinguishable from hemorrhoids since a causal connection is unproven. $(18,19)$. Histologically, thrombi are found in perianal veins, not in subcutaneous tissue and the term "hematoma" is wrong. (5). TEH has two main modalities of clinical presentation: as a common single external pile or as a circular thrombosis of external hemorrhoids. Thrombosed hemorrhoid, treated with incision and removal of clot. Image courtesy of Dr. Jonathan Adler. $(20,21)$ Acute pain and thrombosis of an external hemorrhoid within 48-72 hours of onset is an indication for excision (22) inject local anesthesia into anal skin which is very painful, do an incision or excision, and then take thrombi out. $(5,16,17,19,23,24)$ Is this necessary? Only a minority of such patients present with formidable swelling, fierce bleeding, and overwhelming pain. Because patients fear surgery, they wait and observe their symptoms. Sometimes they present hours, even days after onset with less swelling, less pain, and no bleeding. Because swelling vanishes, a thrombus must not perforate anal skin, which means no bleeding, and may disappear within two to three weeks by resorption.

\section{Aims of the study}

Some patients refuse operation for thrombosed external heamorrhoid either because afraid or shying especially female patients in our society, the aim of this study is possibility to treat patients who complain from thrombosed external heamorrhoid with out operation only conservative management with minimal risks and complications

\section{Methods and procedure}

20 Patients with TEH (12 men ,8 women ), aged 17-65 years9(mean age $47 \mathrm{y}$ ), presenting at my office from jun 1st, 2011 to jun, 2012 at $\mathrm{Al}$ Hussain teaching hospital in Nassyria and at my privet clinic (all of them refuse operation ) management policy is No surgery, conservative management including use smooth dry toilet paper for anal cleaning after defecation, with use topical anesthesia (lidocain 2\% ointment) As well as intravenous antibiotics (cefetriaxazon and metronodazol) and stool softeners, increased dietary fiber, increased fluid intake, analgesia. The management continue for one to two weeks (not use water or wet wipes), then follow patients for 6 months were instructed to come back to clinic in case of problems or recurrence.

\section{$\underline{\text { Results }}$}

This study was done on 20 patients all of them complained from external thrombosed heamorrhoid 12 men about $60 \%$ and 8 women about $40 \%$ as I table 1 from different age groups 
as in table 2 in mean age 47 years, they were complained from different associated symptoms mostly itching $75 \%$ lump and pain $60 \%$ look table 3 . After 1 to 2 weeks of conservative management 6 patients $30 \%$ were healed, while 10 patients $50 \%$ unchanged not disappear but still complaining from very negligible symptoms they were not need operation look table 4 , there are 4 patients $20 \%$ complain from sever pain and abscess formation so that urgent operation was done.

The 16 patients who not undergo operation I continue follow them for 6 months to show any recurrence of disease, the result is only 2 patients $12.5 \%$ have recurrence of disease while others 14 patients $87.5 \%$ no recurrence

Table (1): Sex distribution.

\begin{tabular}{|l|l|l|}
\hline Sex & No of Pt & $\%$ of Pt \\
\hline Males & 12 pt & $60 \%$ \\
\hline Female & $8 \mathrm{pt}$ & $40 \%$ \\
\hline Total & $20 \mathrm{pt}$ & $100 \%$ \\
\hline
\end{tabular}

Table (2) Age distribution the main age about 47 $\mathrm{y}$ in both sex its distributed as below

\begin{tabular}{|l|l|l|}
\hline Age & No of $\mathrm{Pt}$ & $\%$ of Pt \\
\hline$<30 \mathrm{y}$ & $2 \mathrm{pt}$ & $10 \%$ \\
\hline $30-40 \mathrm{y}$ & $5 \mathrm{pt}$ & $25 \%$ \\
\hline $40-50 \mathrm{y}$ & $7 \mathrm{pt}$ & $35 \%$ \\
\hline$>50 \mathrm{y}$ & $6 \mathrm{pt}$ & $30 \%$ \\
\hline Total & $20 \mathrm{pt}$ & $100 \%$ \\
\hline
\end{tabular}

Table (3) Most of Patients complained from at least one or 2 symptom:

\begin{tabular}{|l|l|}
\hline Itching & $15 \mathrm{pt}(75 \%)$ \\
\hline lump & $13 \mathrm{pt}(65)$ \\
\hline pain & $12 \mathrm{pt}(60)$ \\
\hline bleeding & $3 \mathrm{pt}(15 \%)$ \\
\hline Mucous discharge & $1 \mathrm{pt}(5 \%)$ \\
\hline
\end{tabular}

Table (4) after 2 weeks of conservative management

\begin{tabular}{|l|l|l|}
\hline & No of $\mathrm{Pt}$ & $\%$ of Pt \\
\hline Healed & $6 \mathrm{pt}$ & $30 \%$ \\
\hline Unchanged & $10 \mathrm{pt}$ & $50 \%$ \\
\hline Pain or abscess & $4 \mathrm{pt}$ & $20 \%$ \\
\hline Total & 20 & \\
\hline
\end{tabular}

Table (5) after six-month follow-up (range 2-10 months) most of healed and unchanged patients have no recurrences

\begin{tabular}{|l|l|l|}
\hline & No of $\mathrm{Pt}$ & $\%$ of $\%$ \\
\hline no recurrences & 14 & $87.5 \%$ \\
\hline recurrence, & 2 & $12.5 \%$ \\
\hline Total & 16 & $100 \%$ \\
\hline
\end{tabular}

\section{Discussion}

In this study I choice 20 patients (12 males , 8 female) with main age about 47 years in both sexes all of them complained from Thrombosed external hemorrhoid, most of them afraid from operation, some female patients shying was included, as in table 1,2 With symptoms at admission were: anal lump ,pain , burning ,itching , bleeding, pricking and so.. as in table 3. All of them treated with conservative management no surgery (with gentle dry cleaning with smooth toilet paper after defecation. As well as antibiotics (cefetriaxazon and metronodazol) and stool softeners, increased dietary fiber, increased fluid intake, analgesia) some of them healed without need any surgical operation $6 \mathrm{Pt}$ out of $20(30 \%)$ look (table 4). The swelling vanishes, a thrombus not perforate anal skin, which means no bleeding, and disappear within two to three weeks by resorption. , $(23,24)$, and some other patients 10 patients $(50 \%)$ THE still unchanged but with minimal symptoms but not disappear, while 4patients $(20 \%)$ not respond to management become sever pain or development of abscess, so operation was done urgently. After six-month follow-up (range 2-10 months) most of healed patients or unchanged patients have no recurrences 
14 Pt out of $16(87,5 \%$ healed with out recurrence) table 5. There are no randomized controlled trials comparing surgical and conservative management of THE, because the surgical management is the gold standard if the condition is encountered within the first 72 hours after onset or fails to respond to conservative treatment Acute pain and thrombosis of an external hemorrhoid within 48-72 hours of onset is an indication for excision. In a retrospective study by Greenspon et al, surgical treatment resulted in much faster symptom resolution ( $3.9 \mathrm{~d}$ vs $24 \mathrm{~d}$ ), as well as a lower frequency of recurrence $(6.3 \%$ vs $25.4 \%),-(25)$

\section{Conclusions}

In spite of the surgery is regarded the gold standard therapy for TEH but the use conservative management its a good alternative treatment for patients who refuse surgery with minimal risks and complications but should good follow up

\section{$\underline{\text { References }}$}

(1)-Feldman M. Hemorrhoids.2002 In: Sleisenger \& Fordtran's Gastrointestinal and Liver Disease. $7^{\text {th }}$ ed. Elsevier;:2281-82.

(2)Oh C. 1989 Acute thrombosed external hemorrhoids. Mt Sinai J Med. Jan;56(1):302.

(3)Tan KY, Seow-Choen2007 F. Fiber and colorectal diseases: separating fact from fiction. World $J$ Gastroenterol. Aug 21;13(31):4161-7.

(4)Alexander-Williams J. 1983 Pruritus ani. $\mathrm{Br}$ Med J (Clin Res Ed).; 287:159-160.

(5) Hancock BD. 1992 ABC of colorectal diseases. Haemorrhoids. BMJ.;304:1042-1044.

(6)Janicke DM, Pundt MR. Surgical excision of symptomatic thrombosed external hemorrhoids is indicated within 48 to 72 hours of pain onset. Emerg Med Clin N Am. 1996; 14:757-758.

(7)Nelson LR. 2003 Treatment of anal fissure. BMJ.;327:354-355.

(8)Abramowitz L, Sobhani I, Benifla JL, et al. 2002 Anal fissure and thrombosed external hemorrhoids before and after delivery. Dis Colon Rectum.; 45:650-655.

(9)Oh C. 1989 Acute thrombosed external hemorrhoids. Mt Sinai J Med.; 56:30-32.

(10)Perrotti P, Antropoli C, Molino D, et al2001. Conservative treatment of acute thrombosed external hemorrhoids with topical nifedipine. Dis ColonRectum.; 44:405-409.

(11)Eisenstat T, Salvati EP, Rubin RJ. 1979 The outpatient management of acute hemorrhoidal disease. Dis Colon Rectum.; 22:315-317.

(12)Arthur KE. 1990 Anal haematoma (coagulated venous succule or peri-anal thrombosis). Rev Med Panama.; 15:31-34.

(13)Delaini GG, Bortolasi L, Falezza G, et al. 1995 Hemorrhoidal thrombosis and perianal hematoma: diagnosis and treatment. Ann Ital Chir.; 66:783-785.

(14) Iseli A. 1991 Office treatment of hemorrhoids and perianal hematoma.Aus Fam Physician.; 20:284-290.

(15) Thomson H. 1982The real nature of "perianal haematoma". Lancet.; 8296:467-468.

(16)Gai F, Trecca A, Suppa M, et al. 2006 Hemorrhoidal thrombosis.A clinical and therapeutic study on 22 consecutive patients. Chir Ital.; 58:219-223.

(17)Nieves PM, Perez J, Suarez JA. 1977 Hemorrhoidectomy - how I do it: experience with the St.Mark's Hospital technique for 
emergency hemorrhoidectomy. Dis Colon Rectum.; 20:197-201.

(18)Barrios G, Khubchandani M. Urgent hemorrhoidectomy for hemorrhoidal thrombosis. Dis Colon Rectum. 1979; 22:159-161.

(19)Brearly S, Brearly R. 1988 Perianal thrombosis. Dis Colon Rectum.;31:403-404.

(20)Abramowitz L, Sobhani I, Benifla JL, Vuagnat A, Daraï E, Mignon M, et al. 2002 Anal fissure and thrombosed external hemorrhoids before and after delivery. Dis Colon Rectum. May; 45(5):650-5..

(21)Cheng CY, Li Q. 2008 Integrative review of research on general health status and prevalence of common physical health conditions of women after childbirth. Womens Health Issues. Jul-Aug; 18(4):26780.

(22)Cavcic J, Turcic J, Martinac P, Mestrovic T, Mladina R, Pezerovic-Panijan R2001. Comparison of topically applied $0.2 \%$ glyceryl trinitrate ointment, incision and excision in the treatment of perianal thrombosis. Dig Liver Dis. May;33(4):33540 ..

(23)Jongen J, Bach S, Stuebinger SH, et al. Excision of thrombosed external hemorrhoid after local anesthesia. A retrospective evaluation of 340 patients. Dis Colon Rectum. 2003;46:1226-1231.

(24)Sakulsky SB, Blumenthal JA, Lynch RH. 1970 Treatment of thrombosed hemorrhoids by excision. Am J Surg.;120:537-538.

(25)Greenspon J, Williams SB, Young HA, Orkin BA. 2004 Thrombosed external hemorrhoids: outcome after conservative or surgical management. Dis Colon Rectum. Sep;47(9):1493-8. 